\title{
The female Klebun of Madura within the power constellation of the patriarchy: A post-colonial feminism perspective
}

\author{
Aminah Dewi Rahmawati ${ }^{1 *}$, Emy Susanti ${ }^{2}$, Bagong Suyanto ${ }^{3}$ \\ ${ }^{1}$ Faculty of Social and Political Sciences, Universitas Airlangga, Indonesia \\ ${ }^{2,3}$ Department of Sociology, Universitas Airlangga, Indonesia \\ * Corresponding author \\ E-mail address: aminahrahmawati75@gmail.com \\ DOI: https://doi.org/10.21107/sml.v4i1.10391
}

\begin{tabular}{|c|c|}
\hline Article Info & Abstract \\
\hline $\begin{array}{l}\text { Keywords: } \\
\text { female Klebun } \\
\text { subaltern } \\
\text { patriarchy culture, } \\
\text { postcolonial- } \\
\text { feminism } \\
\text { Madurese society }\end{array}$ & $\begin{array}{l}\text { During the Indonesian reformation era, Madurese politics began to see a } \\
\text { notable increase in women participation. One indicator is the increasing } \\
\text { number of female village chiefs, locally referred to as Klebun, who occupies } \\
\text { the highest leadership position within Madurese villages. An in-depth } \\
\text { interview with two female Klebuns and three informants revealed that } \\
\text { female Klebun in Madura represents women and extended kinship interests } \\
\text { in continuing dynastic politics. The female Klebun experienced a subaltern } \\
\text { form of relationship with the largely patriarchal system they find themselves } \\
\text { in, marked by coercion, threats, pressure and lack of freedom in their } \\
\text { candidacy and village leadership. The lack of any communicated objections } \\
\text { from the female population over these repressive actions is due to the strong } \\
\text { dominance of patriarchal culture in Madurese society. This research uses } \\
\text { a descriptive qualitative approach. The primary data used are the results } \\
\text { of interviews with five informants. Secondary data used consist of relevant } \\
\text { scientific journals, articles, and books. This research is conducted under the } \\
\text { framework of postcolonial feminism. }\end{array}$ \\
\hline
\end{tabular}

Citation suggestion:

Rahmawati, A. D., Susanti, E., \& Suyanto, B. (2021). The female Klebun of Madura within the power constellation of the patriarchy: A post-colonial feminism perspective. Simulacra, 4(1), 87-99. https://doi.org/10.21107/sml. v4i1.10391

Received 10 April 2021; Received in revised form 10 May 2021; Accepted 25 May 2021; Published online 25 June 2021. 


\section{Introduction}

Thenumber of women involved in politics in Indonesia has continued to increase. This can be inferred from the rising number of female politicians elected as members of the regional and national people's representative councils and those elected into both regional leadership positions as governors and in the municipal levels as mayors and regents. The exact margin of this increase varies from year to year, as reported by the Association for Elections and Democracy (PERLUDEM). In 2015, women who won in the gubernatorial elections reached a margin of $8.7 \%$. In 2017 there was a decrease in the percentage of elected female candidates, which only reached themargin of $5.9 \%$. In the 2018 general elections, out of 342 elected regional heads, 31 female candidates were elected $(9.06 \%)$ (PERLUDEM, 2021). These figures show an increase in women's political participation. Their presence encourages positive change regarding female representation in the public and political spheres (Wuisan, 2013).

The increase in women's involvement in political and governmental leadership positions has also reached Madura, where patriarchal values form the basis of social and political life. In the socio-cultural structure in Madura, women have traditionally been placed in the domestic sphere, while the public sphere is the domain of men (Karim, 2007). Tulistyantoro (2014) states that this patriarchal power is reflected in the arrangement of the tanean lanjeng (traditional Madurese house), which places the men's chambers at the front and the women's living space at the back. This house arrangement illustrates that affairs with other people are the domain of men, while women are assigned the role of housekeeping and homemaking. More broadly, the patriarchal system in Madura has regulated women and men in their rights and obligations. Consequently, the role of being involved with activities related to politics and power has been assigned to men (Hefni, 2012). According to Hidayati (2009), few Madurese women are given political roles due to the politics and leadership roles having been assigned to men, while public activities for women take the form of cultural activities in the form of social gatherings such as weddings, funerals, and religious gatherings (Hidayati, 2011).

For this reason, it must be noted that women's involvement in politics remains under the shadow of patriarchal power. The reality is that female politicians in Madura cannot be separated from their male relatives already occupying established political positions. Further securing the power of an already established political dynasty has always been the driving force behind female political leaders in Madura in the first place. Women are chosen to replace husbands, fathers, or other male relatives who can no longer run again in the candidacy arena for various reasons. Dynastic politics in village leadership positions in Madura has dragged Madurese women into politics. The inheritance system model influences the rise of female Klebun in Madura. Satriyati (2009) argues that the inheritance system is one of the dominating models for forming village chief power in Madura. Inheritance is usually obtained from their husband or father. This inheritance model shows that behind the leadership figure of the female Klebun, patriarchal family interests are dominant.

The emergence of political dynasties in Madurese politics, specifically in Klebun or village chief, is caused by broad powers attached to the said leadership position. The village chief is an administrative position as stipulated in the Village Government Law and a position occupying a central role in any given village's socio-economic and socio-political circles. Access to power and control over social spaces has made village chiefs highly respected in their 
respective communities. In the economic field, the village chief can manage resource allocation and finances within the village. In the political field, village chiefs can cultivate favourable relations with political figures such as party members and prospective electoral candidates when political events and regional elections are held.

This then becomes the patriarchy's shadow that continues to loom over Madurese women involved in village politics. Women are seen as only having power in a representative manner, whereas when examined substantively, men continue to hold power through their female relatives who have been elected into leadership positions (Ida, 2001). Researcher at the Indonesian Centre for Islamic Studies and State (PSIK), Arif Susanto, said that women are vulnerable to becoming victims in dynastic political practices. Some women in elected positions in the Madura tend to be elected because of patriarchal backgrounds, specifically their male relatives' names and associated powers. These male relatives also influence policy-making decisions during the elected female leader's period of office (Yusri \& Adlin, 2020).

Hidayati (2015) assesses that kalebun babine (female village chief) still leaves a lingering question on whether they are present as actual decision-making leader figures or is merely a facilitator for the continuation of power already held by their extended family. With a cultural construction and a hidden transcript approach, it appears that the figure of the female Klebun is dominated by patriarchal power. The practice of the patriarchy's domination in the leadership role of female Klebun was found by Holilah (2015), who found dysfunction in the leadership role of female Klebun in the village of Masaran, Banyuates District, Sampang Regency due to her inability to manage village leadership tasks which are still fully managed by her husband who was the previous village chief. On the other hand, independent and creative female Klebun was found in Karim's (2007) and Satriyati (2009) research. In addition, Sabariman (2019) found that female Klebun who can lead the village of Ponteh, Galis District, Pamekasan Regency successfully have a certain leadership style. Success is measured by the ability to complete administrative tasks and other tasks. Support from officials and residents are the key to the success of her leadership.

Similar approaches were used by Hidayati (2015) in observing the leadership patterns of Madurese female Klebun place women as objects of patriarchal power. The presence of female Klebun in the various approaches taken by Hidayati shows that it is difficult for women to be 'independent' in managing their responsibilities as village chiefs because of the very strong and influential forces behind them.

This present study in the feminism landscape leads to a post-colonial feminist approach that takes a patriarchal background as one of the cultures that participate in domination and subordination in third world countries. In the post-colonial feminist landscape, the presence of women in various positions must be both representative and substantive (Loomba, 2016). Post-colonial feminist figure Spivak (2010) argues that women's involvement is not only seen in the form of vocal representation in public but, more importantly, in the purpose behind their appearance and involvement in such activities. For post-colonial feminists, women's participation has not answered the extent to which feminist awareness and agendas already exist in that space. This is because women are very vulnerable to their position as representation when coupled with other orientations. In this case, colonization often occurs in spaces of women's representation. Spivak reminds us that colonialists often paint themselves as 
ethical saviours when they have always been motivated by their own interests.

Post-colonial feminists view women in a subaltern position, a graphic representation of the subordinate relationship between the patriarchal power and the figure of the female Klebun in Madura. This can be seen from several elements. First, in the subaltern space, some situations and conditions describe subordinate relations so that the subaltern is often synonymous with subordinates. Second, women were one of those groups in various colonial contexts who had no resistance or the ability to voice their concerns, needs, and aspirations. Third, women are no longer seen as equal to men, but they are in the second sex position, which tends to be victims of patriarchy (Spivak, 2010).

The presence of women in the midst of the patriarchal Madurese society poses a significant and impending question. Although looking back at the background of their presence, the existence of female Klebun cannot be separated from the interests of continuing the power of their family (dynasty), this phenomenon will give birth to domination practices, which place women on subjects who experience subordination. All these forms of subordination can put women in a subaltern position.

\section{Method}

This study employed a qualitative method with a feminist ethnographic approach. The qualitative method was expected to provide a detailed description of the background, experiences, and trinkets that occur in Madurese women in politics and patriarchy (Karim, 2014). According to Vanderstoep (2009), descriptive objectives are part of the characteristics of qualitative research. Qualitative research aims to understand, in-depth, a social reality from the perspective of research subjects.
Recognizing that all understanding is built by research subjects, each individual or different group of people will have different interpretations of their own experiences and the social systems in which they interact. In addition, the researcher will place the researcher's own cultural, social, and personal identity in any interpretation of the experiences of the research subject.

The feminist ethnographic approach, according to Reinharz (1992), is a research approach that has the following objectives. First, feminist ethnography tries to document the various activities and lives of women. Second, feminist ethnography moves to the activity of understanding women from a women's perspective. Third, efforts to conceptualize various behaviours carried out by women in responding to situations in specific social contexts, in a series of perspectives on gender relations. Finally, the feminist ethnographic approach will provide space for female subjects to describe their experiences, backgrounds and situations and conditions experienced.

In the political sphere, feminist ethnographers are believed to be able to become ethnographers as disseminators and solutions providers because ethnographers do not only listen to but also write about the lives of marginalized groups in society (Idrus, 2006). Willis (1977) explains that the work of ethnographers will revolve around three things. First, to become a link between structure and agency which illustrate that there are forms of injustice against women in this relationship. Second, ethnographers will be able to dismantle relations based on gender, race and class. Third, ethnographers will be able to dismantle forms of domination and subordination in cloned women's living spaces and efforts to liberate them from this situation.

Data collection for this study was carried out by conducting in-depth interviews, observations, documents, and audio 
visuals. Interviews were conducted with two primary informants and three auxiliary informants. The two primary informants were female Klebun from the villages of Pocong and Bilaporah, Bangkalan Regency, with the three auxiliary informants being the assistant staff members of the Bilaporah Village Finance Department. The method in choosing informants was done through the snowball method. Interviews were conducted on 24 and 25 January, 25 and 27 February, and 2 March 2021 at the respective Klebun's residences and the informants' office.

The data analysis process was carried out by sorting data oriented towards manageable data units, synthesizing data, finding important points in research so that they can formulate subaltern realities experienced by subjects with structures, and describing these phenomena in the narrative of the research results.

\section{Results and Discussion}

This research was conducted in the Bangkalan Regency area, which is located in the West End region of Madura. Bangkalan Regency is the closest area to Java and is separated by the Madura Strait. For this reason, Bangkalan serves as the gateway to enter Madura. In addition, the connection between Java and Madura through the Suramadu Bridge places Bangkalan City directly connected to the Surabaya, the regional capital of East Java.

Bangkalan consists of 18 districts and 273 villages. It has a population of approximately one million people, with agriculture as the main livelihood. However, many of the socioeconomic problems in the region are caused by poverty. Indeed, Bangkalan was listed as underdeveloped areas from 2015 to 2019. This is based on several criteria, including the community's economic condition, human resources, regional financial capacity, accessibility, and regional characteristics.

In 2021, four women become members of the Bangkalan regional council of representatives, DPRD, and ten become female Klebun. Madura female Klebun leads administrations located in remote areas of Bangkalan, such as Pocong Village in Tragah District, Tonggangat Village in Tanjung Bumi District, Bancang Village Tragah District, Polangan Village in Klampis District, and Bilaporah Village in Socah District. Apart from being located in the more remote areas of Madura, these villages are prone to be affected by criminal activities such as theft, drugs, and conflicts leading to carok, a form of honour killing among the Madurese. This happens because in the village community, the power and authority of the local criminal elements, colloquially known as blater, are still important element in society. In Rozaki (2004), it is explained that the role of the blater goes hand in hand with the role of the kyai or local Islamic cleric in Madurese society. Blater is a community born from cultural and economic strength. On the other hand, the kyai is a figure born from a religious space (Jannah \& Ida, 2019; Sukri, 1999). These two forces are important elements that affect people's lives, in economic, social, and political life (Rozaki, 2016).

\section{The system of Klebun election in Bangkalan}

Village chiefs in Indonesia are regulated under the Indonesian Law No.6 of 2014 concerning Villages, which includes regulating the election of village chiefs. The village chief is elected by and from villagers who are citizens of the Republic of Indonesia who meet the requirements with a term of 6 (six) years. The village chief may serve for a maximum of 3 (three) terms in office, either consecutively or not.

A person may ascend into the Klebun position through elections and replace 
Klebun who cannot continue their duties in the middle of the period (Pergantian Antar Waktu or PAW). PAW is carried out when the previous village chief dies, is dismissed, or resigns before their term of office ends. Based on the regional regulations or Perda Bangkalan number 1 of 2015 regarding village chief elections, a replacement is chosen through village deliberations. However, in practice, a replacement Klebun is chosen from a close relative of the previous Klebun, who is usually his child or wife. A son who meets all the necessary administrative requirements, especially age and education, is still the ideal choice. However, if such a figure is unavailable, the closest adjacent female figure will be elected.

Sumiani is the Head of Bilaporah Village, who held the position of village chief through the PAW process after her husband Haji Musni Moche, who was elected in the village chief election in 2016, died. Haji Musni Moche died in his second year of office and was succeeded by his wife, Sumiani. As Sumiani put it (interviewed 24 January 2021):

"I have served as village chief in Bilaporah since 2018 from the PAW mechanism (continuing the term of office) of my husband, who died in 2017. Because our children are still not old enough, I am the one who continues the position of the village chief. When they are old enough, they will run for elections in 2022" (Interview, Sumiani).

The above statement shows how Madurese society views women as occupying a subordinate role to the power and dominance of men. In this case, the female Klebun is seen as an extension of her husband and sons' power, and her term in office is part of her service to them. Female Klebun, therefore, are not present as leaders, instead of as inheritors and 'key bearers' of their male relatives' powers. Their role is to safeguard their male relatives' power from falling into another family's hands and to transfer said power over to the following male relative when one presents himself.

In a patriarchal society, women are seen as subordinate to the power of men (Sultana, 2012). Therefore, she is seen not as an individual in her own right. Instead, she is seen in a society strictly as a daughter obligated to her father, a wife obligated to her husband, and a mother obligated to her sons. This perspective dictates society's views and attitudes in choosing a Klebun through the PAW process.

This PAW system is quite unique in Bangkalan because this method is not written in detail in the legal regulations. The regional regulation only states that if a Klebun dies, is relieved of their duties, or chooses to resign, and a new Klebun will be appointed through village meetings. There are no provisions on how to nominate candidates, prove the process is fair, and there is no requirement for the name submission process to be carried out openly.

The Bangkalan government only explains that village meetings are held following existing local norms and values and is part of the so-called local wisdom. Considerations for implementing this system are the public's willingness to retain the former incumbent's relatives as successors to carry out his remaining term in office. One main takeaway from this system is the showcase that Madurese culture still uses a strong patriarchal approach that continues to dominate local political governance, with male relatives of the former incumbent, the successor from the PAW process, being preferred over other candidates.

Although some female Klebun were appointed because of the PAW process, some have been elected into office. Individuals or groups can nominate candidates. In fact, female Klebun from both of the processes were not intended to be independent public representatives. As Wardani \& Subekti (2021) 
and Watson (2014) explained, women in politics often used to build political dynasties and strengthen family positions in power. They are nominated based on calculating the chances of victory and administrative reasons rather than women empowerment.

\section{The determining factors of women taking the Klebun position}

Female Klebun usually are former Klebun relatives. Most of them continue their husband's tenure through the PAW mechanism. Hidayati (2015) finds they took office more because of the interest of relatives rather than personal will. Both methods, election and PAW, build political dynasties in Madura villages. Kinship groups want to build or enhance their power in society, which is usually pinned on people with wealth, physical strength and network (blater), religious leaders (kyai), and charismatic people in Madura (Zamroni, 2007).

The presence of female Klebun in Madura is driven more because of external factors than internal factors. Women's motivations in participating in village chief elections are duty given by a husband to his wife or father to his daughter (Hidayati, 2009). For example, Siti Fadilah experienced her husband's intense pressure to be the village chief in Desa Pocong in an interview on 25 January 2021:

"I never imagined that I would become a village chief before because I was mainly a vendor in the traditional market. However, because my husband had to return to the armed forces, he had to choose whether he wanted to remain as village chief or return to his unit. In my opinion, he should return to his unit because it has a longer working period, and he will get retirement benefits. However, it makes me have to replace my husband as a candidate for village chief because my son is not old enough to be nominated. I refused because I am not ready, but my husband kept pushing me. Finally, he 'threatened' that he would quit his job as a civil servant and would run as Klebun again." (Interview, Siti Fadilah).

Siti Fadilah was elected as the Klebun of Pocong Village by running for the village chief election in 2016. Her husband, Masturi, was the former Klebun of Pocong village. In 2014, near the end of his tenure as Klebun, Masturi was appointed to serve in the armed forces, which forced him to choose. In order to maintain his position in the village, Masturi assigned his wife to run in the election for the next term.

Siti Fadilah's refusal was always followed by the 'threat' from her husband that he would just leave the civil servant job. Meanwhile, for Siti Fadilah, her husband's job as a civil servant is critical in supporting the family. This also made her obey his husband's orders to become the village chief.

This indicates that the emergence of female Klebun does notimmediately indicatea change in perception and culture in Madurese society regarding women in leadership positions. Several female leaders are only extensions of their husbands' political will and are basically glorified 'benchwarmers' for their sons (Hidayati, 2015). Therefore, it is not surprising that the required legal and administrative requirements of Siti Fadilah's participation in the Klebun elections were exclusively cared for by Masturi. Siti Fadilah recounts:

\footnotetext{
"My husband took care of all the processes and requirements for the elections because I really did not want to be elected. Although my husband was excited to take care of my candidacy, I had no choice. It was hard for me to be the Klebun because I had no experience in leadership at all. Moreover, in society, it is still considered taboo for women to lead" (Interview, Siti Fadilah).
}

This study uncovered how patriarchal domination affects each step of the process 
of a female Klebun being elected and placed in power. This result is in line with Hidayati (2015) findings, which states that there are still many issues attached to the position of women as Klebun. This research discovered forms of domination by male relatives towards female Klebun in the form of "coercion" to run for Klebun, which was considered very heavy by the women involved due to their own self-professed lack of knowledge and experience. In addition, the interest in power becomes the dominant motivation of male relatives when proposing women as a substitute because women are easier to manage and control.

The same phenomenon was experienced by Sumiani, who had to continue her husband's village chief in Bilaporah Village, Socah District. After her husband, the incumbent Klebun, passed away, her relatives urged Sumiani to continue his remaining term of office through the PAW mechanism. Thus, she had to fulfil that social pressure.

Female Madurese Klebun who experienced 'coercion' to take the position of a village chief in the post-colonial feminist approach experience what Spivak indicates as subordination and domination by husbands, relatives, and in-laws to the wife figure. Everything related to the wife's activities is the right of the husband or relatives to determine. This can be seen from the existence of "coercion" on women who have to accept "duties" in the running for village chief against their own will. This is a burden and pressure for women because being the village chief is more like obeying orders from a husband or relative than on her own accord. The opinions of women who rejected the idea became voices that their husbands or relatives did not hear. This is what places the female village chief in a subaltern position.

\section{Female Klebun in fulfilling the leadership duties of a village chief}

In general, the duties of the village chief in Bangkalan are divided into two, tasks given by laws and regulations and tasks given by the community. According to Article 26 of the Indonesian Law No 6 the Year 2014, the duties of the village chief are organizing village government, implementing village development, and empowering the village community. Apart from these obligations, there are social tasks that are not included in the legal framework. This includes attending an invitation from residents, visiting sick people or being affected by disasters, attending the funeral of deceased residents, and resolving conflicts between residents. In addition, the community also expects that the village chief will be involved in solving community problems related to law violations, such as removing people who commit murder and abuse drugs from prison and be able to find stolen items and redeem them from a thief to return it to its owner.

These tasks require a Klebun to possess the necessary will, fortitude, and strategic way of thinking to carry them out ability and courage to be completed with specific strategies. In reality, it is found that women are never adequately prepared to lead effectively, so that in completing these tasks, the female village chief is only in administrative symbols, while the husbands or male relatives are the ones who truly implement substantive changes and decisions. The following is recounted by Sumiani (interviewed 27 February 2021):

"I leave all administrative tasks to the village secretary because I do not understand various administrative and financial tasks. The village apparatus will communicate with my son on this matter. I only give my signature for reports or and the like. My son will resolve those matters for social activities such as coming to religious 
events, attending residents' invitations, or solving community problems. I concentrated more on family welfare guidance programmes (PKK) and community health service centre (Posyandu) activities" (Interview, Sumiani).

This opinion was reinforced by the head of the finance department of Bilaporah village, $H$. Ismail, who emphasized that all the affairs and duties of the village chief were handled by the first son of $\mathrm{H}$. Mosni Moche and Sumiani, who have reached legal adulthood. According to $\mathrm{H}$. Ismail, although H. Mosni Moche's son is still relatively young, he is considered mature and physically capable.

In Spivak's post-colonial feminist theory, women as Klebun are in a subaltern experience. The power dominance of male relatives over the female Klebun is apparent from their involvement in her nomination and election process and their active involvement in managing village affairs during her term in office. Women are only positioned as symbols of administrative and legal formality, while male relatives act as the true Klebun in all but name (Holilah, 2015). These pressures the formally appointed Klebun, as society at large sees them only as an authority in name only and shows that the acceptable response of a woman in such a position is polite 'silence' only. This silence is mainly emblematic of their lack of bargaining power due to their limited managerial abilities and experiences, which causes many elected or appointed female Klebun to resign themselves in the position they are in. In addition, when any of them attempt to voice their opinions or express their concerns, they remain unheard due to the strong dominance of the patriarchy.

Other than that, due to their aforementioned lack of experience in leadership positions, female Klebun often experience a dysfunctional pattern of leadership (Holilah, 2015). This is compounded by the fact that in Madura, acceptable activities for women are still limited to 'easy' and otherwise innocuous tasks, as there is still a strong lingering taboo for women to engage in traditionally masculine activities and tasks such as politics, limiting the scope of agency in their lives. This is a clear indication that the power of the patriarchy has become the value that underlines all socio-political activities in rural Madurese communities.

The same situation also occurred in Pocong Village, Tragah District. The village chief, Siti Fadilah (interview 25 February 2021), explained:

\begin{abstract}
"My husband has handled all matters, including village finances. I only took my monthly salary, which was 1.4 million rupiahs. My husband handles all village programs. I only carry out tasks that require me to attend such as meetings in the district or regency and village ceremonial events, such as yesterday, welcoming the Bangkalan Regent's wife to visit village Posyandu activities" (Interview, Siti Fadilah).
\end{abstract}

This study did not find a phenomenon such as in the research of Karim (2007) or Satriyati (2009) and Sabariman (2019), who found that female Klebun was able to carry out her duties using her own distinctive style and take on leadership. Female Klebun continue to fulfil her duties only within the scope and purview of obeying an obligation given to her by her husband. The cultural conditions of the village community significantly affect the leadership style of the female Klebun. The values of appropriateness are still measured from the patriarchal culture of society.

In her explanation, Siti Fadilah revealed that when a woman becomes Klebun they are still seen as a wife first, whom men must still lead. In society, a wife who carries out a more dominant role than her husband will attract ill attention from the public, with her husband often decried as an emasculated 
cuckold who is afraid of his wife. Therefore, the dominance of the husband is very strong in the village community in Bangkalan.

During her position as a Klebun, the values of appropriateness for women interacting with other people are still strongly limited by tradition (Holilah, 2015). For example, is the appropriateness of women to meet guests and outsiders at home. This tradition strengthens the patriarchal culture where men play a role in public spaces and women play a role in the domestic sphere, which is still deeply rooted in Madura. Siti Fadilah stated that for matters of meeting with guests, she would only meet them if allowed by her husband. Before the husband gives permission, the husband will meet guests and settle matters with them, including matters related to her duties as village chief.

In relation to the social duties of a village chief, some of them are carried out by the female village chief themselves because socially, it has become a regular activity such as mourning, tok otok (traditional social gathering), and attending weddings (Hidayati, 2011). However, if the religious event or remoh (traditional social gathering for men with high social status especially blater) event occurs at night requires performing together with men, her husband or male relative represents the presence of female Klebun in the event. Therefore, women are deemed not 'appropriate' or 'good' if appearing side by side in a community attended by men even though they are attending in their capacity as village chief (Holilah, 2015). Other tasks handled by male relatives are to resolve problems and conflicts between residents, including getting residents out of prison, tracking stolen property, and conflicts between residents that often arise due to seizure of women and land. In general, female village chiefs are only trusted in carrying out tasks that have low risk, while "heavy" tasks will be able to be handled by men.
The role of the village leadership style as above is generally accepted as commonplace in villages led by women in Madura. This is because what is seen from the presence of the female village chief is not her personal figure but rather the kinship that lies behind her. This situation is "quietly" understood and allowed by the Bangkalan government as a regular thing. This means that behind the powerful woman village chief, there is actually a director who plays a significant role in all the policies taken (Holilah, 2015).

Spivak's post-colonial study suggests that the silence of women in certain situations is not always because they agree but is influenced by dominant forces such as cultural norms and people's demands (Spivak, 2010). For example, honour killing (Sati) in India illustrates how the strong patriarchal culture and the interests of male relatives to inherit are the reasons for 'eliminating' women under the pretext of religion (Loomba, 1993).

This is similar to the case of the female Klebun; placing women in the midst of power actually aims to save men's power rather than empowering women themselves (Holilah, 2015). This situation shows that women have become a tool for the interests of patriarchal groups to gain and control power. Female Klebun are still expected to limit their powers and expectations in accordance with the existing patriarchal system. This is seen through how they are still expected to obey their husbands will from the candidacy registering process until and into their term in office. Religious and local, sociocultural reasons are often cited as the basis of argument on why female Klebun cannot work without the involvement of male relatives, while in truth, such limitations are caused by her husband or son using her as a proxy to holding power in the village (Hannan \& Abdillah, 2019).

The subaltern experience that covers what women must endure in the political 
sphere, including female Klebun in Madura, must always be voiced. However, in the post-colonial landscape, Spivak argues that the voices of those who experience the subaltern are barely audible unless voiced by intellectuals (Louai, 2012). In addition, strengthening women by increasing leadership capacity is the most effective way to empower women who are 'assigned' to continue the position of their relatives. Not only that, strengthening the network between female Klebun, as well as improving institutions that have a relationship with leadership duties as Klebun, can add experience and strengthen capacity in leadership. This way is intended to ensure that women are more independent and have a bargaining position in the family and community in carrying out their duties as Klebun.

\section{Conclusion}

The appearance of female Klebun cannot be immediately judged as a win for feminism. Given a more in-depth analysis, it is seen that the appointment of female Klebun is primarily based on patriarchal reasonings. Women are considered the subordinate and extension of their husbands and sons' political will and cannot choose their own independently chosen profession. Women must still obey the orders and will of their husbands, including orders to occupy certain political positions.

This impacts how female Klebun are supposed to carry out the duties and functions of leadership. Both primary subjects in this research leave the fulfilment of their supposed duties to sons or husbands who act as the de facto village chiefs, coordinating with the local government apparatus. The female Klebun's presence is merely a formality.

This research corroborated Spivak's point of view, where third-world or countries that have experienced colonialism experience postcolonialism in the form of oppression caused by a patriarchal society. This aligns with the conditions faced by female Klebun experiencing subaltern and patriarchal oppression in Madura. Further research hopes to portray and document female Klebun who are more than just puppets in the shadow of their husbands or sons' administrative and societal influence, who can fully utilize their political station and position to lead their villages independently and effectively indeed.

\section{Declaration of Ownership}

This article is our original work.

\section{Conflict of Interest}

There is no conflict of interest to declare in this article.

\section{Ethical Clearance}

This study was approved by the institution.

\section{References}

Hannan, A \& Abdillah, K. (2019). Hegemoni religio-kekuasaan dan transformasi sosial: Mobilisasi jaringan kekuasaan dan keagamaan kyai dalam dinamika sosiokultural masyarakat. Sosial Budaya, 16(1), 9-24. http://dx.doi.org/10.24014/ sb.v16i1.7037

Hefni, M. (2012). Perempuan Madura di antara pola residensi matrilokal dan kekuasaan patriarkat. KARSA, 20(2), 211-227. http://dx.doi.org/10.19105/ karsa.v20i2.43

Hidayati, T. (2009). Perempuan Madura antara tradisi dan industrialisasi. KARSA: Journal of Social and Islamic Culture, 16(2), 62-74. https://doi.org/10.19105/karsa. v16i2.106 
Hidayati, T. (2011). Kompolan: Kontestasi tradisi perempuan Madura. KARSA: Journal of Social and Islamic Culture, 19(2), 146-166. https://doi.org/10.19105/karsa. v19i2.63

Hidayati, T. (2015). Kalebun bebini': Kontruksi budaya masyarakat Madura dalam melestarikan kekuasaan. KARSA: Journal of Social and Islamic Culture, 22(2), 150-160. https://doi.org/10.19105/karsa. v22i2.525

Holilah, H. (2015). Fungsi dan gaya kepemimpinan kepala desa perempuan di Desa Masaran, Banyuates, Sampang. JRP (Jurnal Review Politik), 4(1), 119-132. Retrieved from http://jurnalfuf.uinsby. ac.id/index.php/JRP/article/view/1041

Ida, R. (2001). The construction of gender identity in Indonesia: Between cultural norm, economic implication, and state formation. Jurnal Masyarakat, Kebudayaan dan Politik, 14(1), 21-34.

Idrus, N. I. (2006). Antropologi feminis: Etnografi, relasi gender, dan relativisme budaya di Indonesia. Antropologi Indonesia, 30(3), 272-296. https://doi/ org/10.7454/ai.v30i3.3568

Jannah, H \& Ida, R. (2019). Lencak: Ruang sosial-keagamaan tokoh agama perempuan Madura. Fikrah: Jurnal Ilmu Aqidah dan Studi Keagamaan, 7(2), 265286. http://dx.doi.org/10.21043/fikrah. v7i2.5060

Karim, A. J. (2007). Kepemimpinan wanita Madura. MIMBAR, Jurnal Sosial dan Pembangunan, 23(2), 221-234. https://doi. org/10.29313/mimbar.v23i2.242

Karim, A. (2014). Feminisme: Sebuah model penelitian kualitatif. SAWWA, 10(1), 8398. https://doi.org/10.21580/sa.v10i1.643

Loomba, A. (1993). Dead women tell no tales: Issues of female subjectivity, subaltern agency and tradition in colonial and postcolonial writing on widow immolation in India. History Workshop
No. 36, Colonial and Post-Colonial History, 209-227. Retrieved from https://www. jstor.org/stable/4289259

Loomba, A. (2016). Kolonialismel paskakolonialisme. Bentang Budaya.

Louei, E. H. (2012). Retracing the concept of the subaltern from Gramsci to Spivak. African Journal of History and Culture, 4(1), 4-8. https://doi/org/10.5897/AJHC11.020

Perkumpulan untuk Pemilu dan Demokrasi. (2018). Potret perempuan kepala daerah terpilih di Pilkada 2018. Perkumpulan untuk Pemilu dan Demokrasi. Retrieved from http://perludem.org/2018/08/01/ potret-perempuan-kepala-daerahterpilih-di-pilkada-2018/

Reinharz, S. (1992). Feminist methods and social research. Oxford University Press.

Rozaki, A. (2004). Menabur kharisma menuai kuasa: Kiprah kyai dan blater sebagai rezim kembar di Madura. Pustaka Marwa.

Rozaki, A. (2016). Islam,oligarki politik dan perlawanan. Pasca Sarjana UIN Sunan Kalijaga dan SUKA Press.

Sabariman, H., Kholifah, S., Yulianti, Y., \& Sobari, W. (2019). Klèbun babine': praktik, gaya kepemimpinan dan faktor pendorong keberhasilan memimpin pemerintah desa. Kafa'ah Journal of Gender Studies, 9(2), 225-234. http://dx.doi. org/10.15548/jk.v9i2.303

Satriyati, E. (2009). The strengthening strategy for women role as decision making, Gender and Politics. Pusat Studi Wanita Universitas Gadjah Mada \& Tiara Wacana.

Spivak, G. (2010). Can the subaltern speak? Postcolonialitat und subaltern articulation. University of Chicago Press.

Sukri, A. S. (1999). Konsep “Bapa' Babu” Guru Raton" pada masyarakat Madura sebagai wujud pengalaman sila ke-2 Pancasila. Jurnal Filsafat. $30^{\text {th }}$ Series, 143153. https://doi.org/10.22146/jf.31708 
Sultana, A. (2012). Patriarchy and women's subordination: A theoretical analysis. Arts Faculty Journal, 4, 1-18. https://doi. org/10.3329/afj.v4i0.12929

Tulistyantoro, L. (2005). Makna ruang pada tanean lanjang di Madura. Dimensi Interior, 3(2), 137-152. https://doi. org/10.9744/interior.3.2

Vandestoep, S. (2009). Reseach methods for everyday. Jossey-bass.

Wardani, S. B. E., \& Subekti, V. S. (2021). Political dynasties and women candidates in Indonesia's 2019 election. Journal of Current Southeast Asian Affairs, 40(1), 28-49. https://doi. org/10.1177/1868103421991144

Watson, D. (2014). Patriarchal barriers to women's political participation in SouthEast Asia: Lessons from Philippines, Cambodia, Malaysia, Indonesia and Timor-
Leste on patriarchy and the rise of women's participation in the state politic. Kemitraan bagi Pembaharuan Tata Pemerintahan.

Willis, P. (1977). Learning to labour: How working class kids get working class jobs. Columbia University Press.

Wuisan, F. (2013). Keterwakilan perempuan dalam politik di lembaga legislatif (Suatu kajian pada DPRD Kota Tomohon periode 2009-2014). Jurnal Politico, 2(1).

Yusri, A., \& Adlin. (2020). The development of political dynasty: Increasing the number of women holding political office in Indonesia. International Journal of Innovation, Creativity and Change, 14(9), 437-446.

Zamroni, M. I., (2007). Kekuasaan juragan dan kyai di Madura, Jurnal Karsa, 12(2), 169-179. http://dx.doi.org/10.19105/ karsa.v12i2.140 